\title{
Nutrienty ve vodách povodí Mostiště
}

\section{STANISLAV JURÁŇ}

Klíčová slova: povodí vodárenské nádrže Mostiště - kvalita vody - modelování emisí nutrientů plošné a difuzní zdroje znečištění - plány dílčích povodí - nápravná opatření

\section{SOUHRN}

Článek prezentuje výsledky projektu zaměřeného na zlepšení situace v povodí vodárenské nádrže Mostiště, kde není dosahován dobrý stav vod z důvodu vysoké zátěže vod nutrienty. $\vee$ návaznosti na získané poznatky je doporučeno $\checkmark$ rámci plánů dílčích povodí zavádět podrobné analýzy v povodích, kde není doposud dobrého stavu vod dosaženo. Za podstatné považuje další doplňování a zpřesňování získaných poznatků u obdobných projektů tak, aby situace mohla být postupně porovnávána v různých oblastech České republiky.

\section{ÚVOD}

Nápravná opatření směřující ke zlepšování stavu vod se realizují postupně jak u bodových, tak i plošných zdrojů znečištění, a to s vysokou finanční zátěží pro společnost. $V$ mnohých prípadech však jasné a průkazné posouzení dostatečnosti či nedostatečnosti opatření pro dosažení cílů $v$ jednotlivých povodích (cílem se rozumí dosažení dobrého stavu vod [1, 2]) chybí. Prakticky se postupuje tak, že za dobu jednoho plánovacího cyklu (období) plánů dílčích povodí dochází podle výsledků monitoringu k vyhodnocení stavu vod. V př́padě nedosažení dobrého stavu vod jsou navrhována opatření, která by měla stav zlepšit. Nikdo podrobně neposuzuje, zda je soubor všech opatření dostatečný a jaký efekt ve vodním toku přinese. Redukce zátěže vod prostřednictvím opatření u bodových zdrojů znečištění bývá numericky podložena, u plošných zdrojů znečištění však tyto informace obvykle chybí. Mưže tak dojít k pochybnostem, zda jsou všechna plánovaná opatření skutečně potřebná a vynakládané finanční prostředky vhodně využity. $V$ některých prípadech se tak bez dalších podrobnějších znalostí a průzkumů o pohybu nutrientů v povodí nebo vodních útvarech neobejdeme [3-6].

\section{OBHAJITELNÝ PŘÍSTUP K DOSAŽENÍ DOBRÉHO STAVU VOD}

Stanovení zátěže vod nutriety ze všech zdrojů znečištění v povodí a vyhodnocení stavu se provádí nejčastěji pomocí modelů [7]. Modely umožňují řadu zjednodušení, nejsou-li potřebná data. $V$ modelech Ize snadno dohledat použitá data nebo výsledky zátěží v obdobných povodích porovnávat. Mezi často používané modely Ize zařadit: Soil and Water Assessment Tool (SWAT), Modelling Nutrient Emissions in River Systems (MONERIS), OECD Modified Methodology, QUAL2K apod.

Podrobnější analýzy $v$ konkrétních povodích mají za úkol kvantifikovat množství nutrientů, jež se dostává do vodních toků daného povodí, analyzovat veškeré zdroje tohoto znečištění včetně plošných zdrojů znečištění v povodí a navrhnout oblasti, kde je možno tyto zdroje optimálně redukovat. Na základě látkového odtoku nutrientů v závěrném profilu povodí vodního toku a odbourávaného znečištění v daném povodí Ize odvodit konkrétní požadavky na redukci výsledných emisí nutrientů. Uvedené analýzy jsou poměrně časově náročné, protože obvykle nemáme k dispozici všechna potřebná data, která následně doplňujeme dalšími měřeními. Vhodné je však kvantifikovat obdobné zdroje emisí nutrientů (cesty), které by se daly, spolu s informacemi o využití území v jiných povodích, v budoucnu porovnávat. V našem případě jsme kvantifikovali zátěž vod nutrienty z obdobných zdrojů znečištění, jako se používá při zpracování Plánu oblasti povodí Dunaje [4].

\section{ZJIŠTĚNÝ STAV V POVODÍ VODÁRENSKÉ NÁDRŽE MOSTIŠTĚ A VÝSLEDKY PROJEKTU}

Za účelem zlepšení situace v povodí uvedené vodárenské nádrže, kde není dosahován dobrý stav vod z důvodu vysoké zátěže vod nutrienty, byl Výzkumným ústavem vodohospodářským T. G. Masaryka, v. v. i., řešen v letech 2014-2015 projekt, který specifikoval jednotlivé zdroje zátěže vod v povodí uvedené vodárenské nádrže. Projekt nevyužíval konkrétní model. Přínos projektu spočíval především ve specifikaci velikosti plošných zdrojů znečištění a odbourávaného znečištění. Na základě výsledkư se dá posoudit, zda bude výhledově možné dosažení dobrého stavu vod, jak je navrhováno v plánech dílčích povodí, nebo na jaká nápravná opatření se dále zaměřit. Projekt s názvem Technické nástroje k identifikaci znečištění byl podporovaný Technologickou agenturou ČR pod č. TD020266. Výsledkem projektu byly mapy prezentující stav zátěže vod z různých zdrojů znečištění. Tyto nástroje (mapy) slouží Krajskému úřadu Kraje Vysočina a dalším veřejným a správním orgánům k usměrňování nápravných opatření.

Vstupními podklady při zpracování projektu byly mapy využití území, ze kterých vyplývá, že v povodí velikosti přibližně 220 km² žije 9100 obyvatel, což je necelá $1 / 3$ průměrné hodnoty udávané pro ČR. V uvedeném povodí je mírně nadprůměrná lesnatost (36,5\%) a vodní plochy (3,5\%) a naopak velmi vysoké procento orné půdy (42,6\%) a odvodňovaných ploch plošnou drenáží (18,5\%), viz obr. 1.

Z výsledků řešení bilancovaného na emise z atmosférické depozice, bodových zdrojů znečištění, zastavěných nepropustných oblastí [8], drenážního odvodnění [8], eroze ze zemědělské půdy (vodní eroze), povrchového odtoku z ostatních ploch (zemědělských, lesních a ostatních) a z podzemních vod je zřejmé, že podrobné podklady o využití území jsou u každého povodí zásadní. Přestože konfigurace zdrojů znečištění je příznivá, včetně výrazného zadržování vod a retence $v$ uvedeném povodí, a podílí se více než $80 \%$ na odbourávání celkového fosforu, dobrého stavu vod na prítoku do vodní nádrže není dosahováno. 


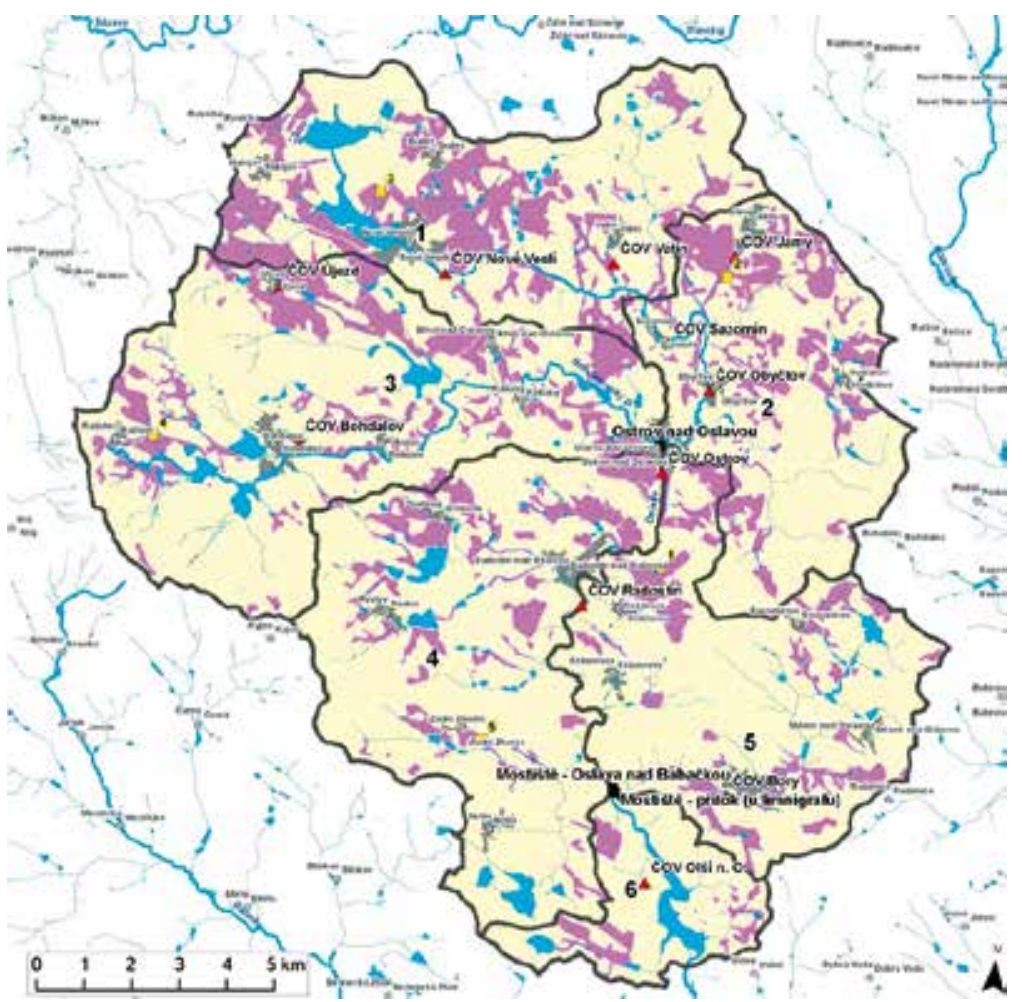

Obr. 1. Rozmístění plošných drenáží v povodí vodárenské nádrže Mostiště

Fig. 1. Layout of planar drainages in the basin of the Mostiště water reservoir

V povodí se vyskytuje 25 obcí a jejich místních částí, kde čištění odpadních vod je až na výjimky co do účinností čištění na nízké úrovni. Celkově je však zátěž od obyvatelstva při uvedené malé osídlenosti nízká a činí u celkového fosforu pouze $18 \%$ z celkové zátěže vod. Z projektu dále vyplynulo, že i kdyby byly čištěny všechny odpadní vody $v$ uvedeném povodí na nejvyšší možnou míru, dobrý stav vod nebude v důsledku vysokých koncentrací tohoto ukazatele dosažen. Je proto nutné plánovat nápravná opatření v povodí, zaměřená především na redukci znečištění z ostatních významných plošných zdrojů znečištění znázorněných v následujícím výsečovém grafu, podle výsledků emisní zátěže (obr. 2).

Za přičinu vysoké koncentrace živin ve vodách se jeví vysoké procento orné půdy v povodía přehnojování zemědělských pozemků. Např́klad na odvodňovaných plochách katastrálního území Kněževes byly naměřeny až o řád vyšší koncentrace dusíkatých látek ve vodách než na odvodňovaných plochách katastrálního území Zadní Zhoř. Omezení vodní eroze je pak zásadním opatřením z pohledu prísunu celkového fosforu do vodních toků. Mimo omezení eroze a hnojení jsou žádoucí další opatření [9], jako je přerušení funkčnosti plošného drenážního odvodnění, zejména v plochách travního porostu, kterých je $\checkmark$ povodí až $1 / 4$ z celkové drenážemi odvodňované plochy povodí. Drenážním odvodněním, způsobem a mírou hnojení spolu s erozním smyvem je proto nutné se dále zabývat. Obdobně tomu bude pravděpodobně i v dalších oblastech, kde navržená opatření $v$ plánech dílčích povodí mohou být nedostatečná. V povodí Mostiště je pak výhodou, že podrobné analýzy jsou již k dispozici. V rámci projektu bylo provedeno celkem 120 laboratorních analýz vod a půd, a proto je možné na výsledky navazovat a také z nich vycházet.

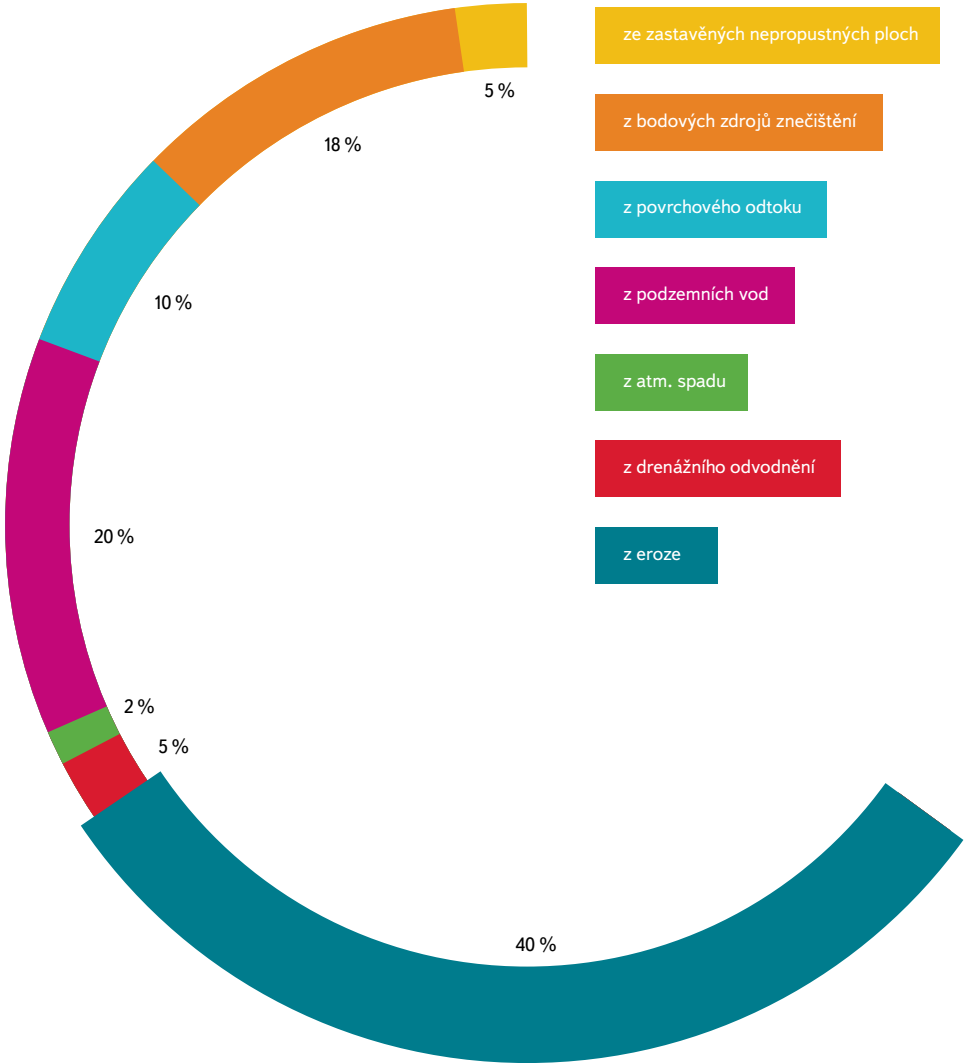

Obr. 2. Emisní zátěž ze zdrojů znečištění v povodí vodárenské nádrže Mostiště v ukazateli $P_{\text {celk }}$

Fig. 2. Emission load from pollution sources in the catchment area of the Mostiště water reservoir in the $\mathrm{P}_{\text {celk }}$ indicator

\section{ZÁVĚREM K ZAMYŠLENÍ}

Uvedený způsob řešení je logickým vyústěním požadavků Rámcové směrnice o vodě, která proces plánování a dosažení dobrého stavu vod iniciovala závazně pro všechny státy Evropské unie. $V$ prípadech nedosažení dobrého stavu vod nám nebude často stačit přijetí nápravných opatření bez doložení jejich účinnosti, a to především u plošných zdrojů znečištění. Využití výpočtových modelů se jeví jako prínosné, protože komplexnost poznatků a značné množství dat se dá snadno vyhodnotit. Rovněž další zpřesňování poznatků o zátěži vod v dalších etapách procesu plánování je bez modelů komplikované a přiznejme si, že u redukce nutrietů se jedná o běh na dlouhou trat'.

Nápravná patření, jak již bylo zmíněno, nejsou zadarmo, a tak bychom měli zvažovat mnohem důsledněji, kde a $v$ jakém rozsahu je uplatnit. K tomuto potřebujeme podrobnější znalosti o všech zdrojích znečištění vod. Je zrejmé, že podrobnější znalosti nejsou potřebné všude, ale přednostně tam, kde je dobrý stav vod nedosažen, což se nejedná v případě České republiky o zanedbatelné území. Napríklad v povodí české části Dyje a Moravy s přítoky Váhu nebylo k roku 2015 dosaženo dobrého stavu vod u 54 \% vodních útvarů z důvodů vysokých koncentrací ukazatelů $\mathrm{P}_{\text {celk, }} \mathrm{N}-\mathrm{NO}_{3}$ a N-NH . Tato skutečnost je sama o sobě alarmující a ukazuje, že k dosažení cílů máme hodně dlouhou cestu. Domnívám se, že přinejmenším u povodí vodárenských nádrží a dalších vodních útvarů napojených na odběry vod, u kterých není doposud dosaženo dobrého stavu vod z důvodu vysoké zátěže živinami, by měly být důvody nedosažení jasněji formulovány s podrobnou analýzou co do výskytu a znalostí všech zdrojů znečištění, tedy především plošných, rozptýlených a těch, které jsou nějakým způsobem propojeny se zemědělskou činností. 
Podrobné analýzy, popř. modely k vyjádření zátěže vod nutrienty jsou jistě žádoucí. Doufejme jen, že se budou dále rozvíjet a doplňovat tak, aby byly srozumitelné a praktické. Není ani tak rozhodující, jaký model použijeme, ale jak dále získané poznatky a analýzy využijeme a prakticky zúročíme. V tomto je potřebné hledat zlepšení.

\section{Poděkování}

Tento př́spěvek vznikl v rámci výzkumného úkolu s názvem Technické nástroje k identifikaci znečištění podpořeného Technologickou agenturou ČR s označením TD020266 (program OMEGA), rešeného v letech 2014-2015.

\section{Literatura}

[1] Nařizení vlády ČR č 401/2015 Sb, o ukazatelích a hodnotách prípustného znečištění povrchových vod a odpadních vod, náležitostech povolení k vypouštění odpadních vod do vod povrchových a do kanalizací a o citlivých oblastech.

[2] Směrnice 2000/60/ES Evropského parlamentu a Rady ustanovující rámec pro činnost Společenství $\checkmark$ oblasti vodní politiky.

[3] BORGVANG, S.A., SELVIK, J.R., GLESNE, O. (ed.) Development of HARP Guidelines - Harmonised Quantification and Reporting Procedures for Nutrients. SFT Report 1759/2000. Oslo, Norway: Norwegian Pollution Control Authority, 2000, 180 p.

[4] SHREIBER, H. et al. Harmonised Inventory of Point and Diffuse Emissions of Nitrogen and Phosphorus for Transboundary River Basin. Research Report 20022 232. Berlin: Federal Ministry of the Environment, Nature Conservation and Nuclear Safety, 2003

[5] European Environment Agency. Source apportionment of nitrogen and phosphorus inputs into the aquatic environment. Denmark, 2005, $48 \mathrm{p}$.

[6] Guidance Document WFD No. 28: Technical Guidance on the preparation of an inventory of emissions, discharges and losses of priority and priority hazardous substances, 2012, 67 p., ISBN 978-92-79-23823-9.

[7] PAVLOVIĆ, M. Diffuse pollution sources and assessment of impacts: overview of methodologies, version 0.2, Zagreb 2010, Technical assistance in the preparation and implementation of the Sava River Basin Management Plan (Ref. No. EuropeAid/128277/C/SER/Multi).

[8] JURÁŇ, S. Podpora způsobu modelovánízátěže nutrienty a účast ČR v aktivitách Mezinárodní komise pro ochranu Dunaje. Zpráva za rok 2008 a zpráva za rok 2009. Brno: VúV TGM.

[9] Identifikace potenciálních zdrojových lokalit plošného zemědělského znečištění - standardizovaný podklad pro projektování komplexních pozemkových úprav. Metodika. Praha: VúMOP, 2008.

\section{Autor}

\section{Ing. Stanislav Juráň}

凶stanislav.juran@vuv.cz

Výzkumný ústav vodohospodářský T. G. Masaryka, v. v. i.

Príspěvek prošel lektorským řízením.

\section{NUTRIENTS IN THE MOSTIŠTĚ RIVER BASIN}

\section{JURAN, S.}

TGM Water Research Institute, p. r. i.

Keywords: Mostiště River Basin - water quality modelling emission of nutrients - surface and diffuse sources of pollution - river basin management plans - measures

The article presents the results of the project aimed at improving the situation in the catchment area of the Mostiště water reservoir where good water status is not achieved because of the high water load of nutrients. In the light of the findings, it is recommended to introduce detailed analyzes in river basins where water quality has not yet been achieved. It is important to further refine and complete the knowledge gained in similar projects so that the situation can be gradually compared in different regions of the Czech Republic. 